担率增加によって，必要な受診をも低下させたかどうか を医療経済学的に検証することは重要な今日的な課題で ある。

【方法と対象】対象保険組合は, 福岡県に所在する $\mathrm{A}$ 健 康保険組合の被保険者とした。高血圧症か糖尿病で 1996 年 9 月より 1997 年 2 月まで 6 ケ月連続して受診し ており，1996 年 9 月より 1999年 8 月まで A 健康保険組 合に所属した全員 171 名とした，定率 2 割負担導入直前 の半年間である，1997年 3 月から 1997 年 8 月までをコ ントロール期間とし，その後 2 年間の受診指標を 6 ヶ月 ごとに比較した。

【結果と考察】高血圧症, 糖尿病ともに定率負担後, 有 意に受診率，完全受診率が低下した，一方，1件当たり 受診日数および 1 件当たり医療費は，導入の後，高血圧 症, 糖尿病ともに, 統計学的に有意な低下は認められな かった.

\section{35 歳時の健診有所見者の受診行動の特徵}

○タナカ千恵子，寶珠山 務, 高橋 謙 (産業医科大・環境疫学)

【目的】わが国の法律で健康診断項目の省略が認められ ている 36 ３9歳の職域人口の受診行動，特に健診有所 見者の特徵を探ること.

【方法】某職域で 10 年間連続して在籍した労働者 10.840 名（男性 6.890名，女性 3.278名）について1988年〜 1997 年の医療費レセプトを(1)断面的および(2)縦断的に 集計し，生活習慣病での医療機関受診率を算出した，次 に 1988 年当時 31 〜 35 歳であった 2,538 名（男性 1,820 名，女性 763 名）について，一般定健の所見の有無別に， 年度別・年齢別の生活習慣病受診率を求めた。

【結果】生活習慣病受診率は加龄に伴って增加し，35歳 時は 30 藏代のほほ中間の值をとった。また，どの年齢 においても健診有所見者は所見のなかった者に比べて受 診率が高かった。

【考察】健診有所見者は所見のなかった者に比べ受診率 が高く, 35 藏時の有所見判定は受診への動機となり得 ることが示唆される.

\section{4. 結核患者の発生と医療従事者に対する対応策につ} いて

○吉川里江，井手 宏，内田和彦，八谷百合子， 織田進（産業医科大・産業医実務研修センター） 結核集団感染は, 大部分が学校や病院・事業所等, 結 核感受性の高い若年者や易感染者が多く接触する場で発 生しているため，このような集団では患者発生の際の対 応についても事前に検討しておくことが，集団感染防止 の上でも, 健康管理上も重要である.

今回，我々は $\mathrm{S}$ 病院において策定された結核感染症対
策マニュアルについて，職員の結核定期外健康診断の流 れを中心に報告する。

マニュアルのフローチャートは主治医からの絬核菌塗 抹陽性の連絡で開始し，その後の緊急 ICG（Infection Control Group）委員会開催や職貝の定期外健康診断実 施，保健所への結果報告まで盛り込んだものである。こ の策定によって, 結核対策における病院や患者発生病棟. 健診を行う健康管理センター等の役割が明確化し, 対応 もより的確で迅速なものとなった，運用上の問題点とし ては，このマニュアルの存在・内容について職貝に周知 徽底する必㱠があることなどが举げられる.

\section{5. 職域成人における生活習慣と口腔内状況との関連}

○尾上佳代子 ${ }^{1}$ ，日野陽一 ${ }^{2}$ ，九万田貫子 ${ }^{3}$ ， 鶴寉美代子 ${ }^{3}$ ，山下直子 ${ }^{4}$, 児玉陽子 ${ }^{4}$

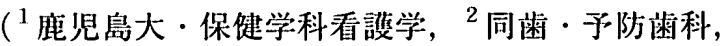
${ }^{3}$ 同柬附属病院， ${ }^{4}$ 山川朾民生課)

職域における健康意識の啓発と積極的な保健行動変容 を目的に，A町役場職貝を対象に歯科健診を組み込んだ 健康実態調查と，歯科健診の結果に基づいた保健指尊を 実施した。

その結果，蒾科健診の結果は，高年齢層に欠損蒌数が 多く現在歯数も少なく，菌周病の槯患割合が高いなど問 題が多く見られた。しかし，歯科保健に関する意識と行 動は年齢による差は見られなかった。また，男女ともに 口腔に注意している人ほど 1 日の茵磨き回数や回腔の注 意個数は多かった。一方，気になることのある人に未処 置菡やトラブル個数が多い割に，菌磨き回数が少なく， 磨いている時間も短いという結果であった。

以上のことを踏まえて，高年齢層はもちろんのこと， 若い時から口腔保健に関心を持って，自分の口腔状態や 保健行動を客観的に評価して，セルフケアができるよう に, 継続的な口腔保健指導が今後とも必要と考える.

\section{6. 労災保険二次健康診断給付事業導入後, 当施設に おける一年間の経験}

○森 朋子，瀨戸 篤，王木屡子，

馬場郁子, 森田哲也（財・福岡学衔衛生研究所） 平成 13 年 4 月より当施設にてこの制度を利用し給付 を受けた134名（男性 113名，女性 21名）について検 討を行った．平均年齢は 47.1 藏であった.

結果は, (1)頝部エコー検查で動脈硬化性病変を認め, 経過観察とされたものが 19 例（14.2\%）で，要精密は 8 例 $(6.0 \%)$ であった. $7 / 8$ 例が 50 墄以上で 1 例 $(0.7 \%)$ に雨中大脳動脈と内頝動脈に狭窄が疑われた．(2)心エコ 一検查にて，31 例（23.1\%）に高血圧性心肥大認め， 1 例で心筋症が疑われた．（3䝺部エコー，心エコー検查と もに異常なし（または心配なし）は79例（59.0\%）で若 